\title{
Imagining social change: Developing social consciousness in an arts-based pedagogy
}

\section{Summary}

This paper is a study of a social-justice, arts-based literacy curriculum in a low income, working-class, predominately African-American school district in Newark, New Jersey. Participating students studied photography and poetry of established artists and took and developed their own photographs accompanied by written narratives. As a part of the curriculum students also wrote poetry and analytical essays. I present my findings within the context of a Vygotskian pedagogical approach that takes social consciousness and metaphor as its central concepts. The paper lays out this conceptual apparatus and deploys it to analyze the curriculum and student work. This paper argues for curricula that develops social consciousness as the most effective for preparing students to create and participate in democratic societies. The research and analysis show that an arts based curriculum, in addition to successfully teaching literacy, is one of the most effective ways of bringing students' life experience into the classroom for analysis and discussion, making activity at school relevant for students lives, especially those whose daily activities regularly confronts issues of life and death.

\section{Introduction}

The No Child Left Behind Act became law in the United States in 2002 escalating pressure on children, teachers, and administrators to perform well on tests or risk loss of federal funding. The law inevitably has led to curriculum that focuses on test preparation and "standards based" assessment with school districts demanding increasing levels of paperwork, and even script based teaching, stifling creativity of the teachers and students alike. According to the Center for Educational Policy (2006) recent report, $71 \%$ of districts are reducing time spent on subjects other than reading and math - with social studies being the subject most effected. Furthermore, elementary schools leaders report a $22 \%$ decline in art and music instruction, and test scores are not improving.

This paper argues that the goal of education should be the development of the whole child: cognitively; emotionally; socially; and physically. Students should be prepared upon graduating for productive and civic participation in society. Such education involves knowledge of and the ability to think critically about the world. It involves the ability to place oneself in this context and to imagine real solutions to improve society for everyone. Pedagogy aimed at developing social consciousness best fulfills this purpose, and, as the research I present below illustrates, art-based pedagogy is especially effective for the development of social consciousness.

The data presented in this article are from a qualitative study of a sixth grade social justice literacy project in a low income, working-class, predominately African-American school district in Newark, New Jersey. The curriculum began with the study of historic 
social and political movements as documented in photography and poetry. Students then took and developed photographs of their community and wrote narratives and poetry around the topic "Where I live." I call this the "Where I Live Curriculum". Through interviews with the teacher, classroom observations, and analysis of curriculum and student work collected throughout the year, this paper examines ways art-based curriculum engages the students and facilitates social consciousness. In particular, I analyze the role of metaphor as a culturally relevant cognitive tool used by the students as they grapple with the complexity of the social world and envision positive social change

\section{Social consciousness, a preliminary definition}

The concept social consciousness organizes my study and it is a key concept for the Vygotskian theory of pedagogy to which I seek to contribute. At the same time, my study is, in part, an attempt to further develop this concept by engaging it with a concrete pedagogy, so the concept will be continuously developed as the research is more systematically introduced throughout this essay. Social Consciousness develops, in an educational setting, in a process involving increasing awareness of social historical context, the ability to think abstractly about time and place, and beyond the immediate everyday conditions to understand individual experience as embedded in a broader system of social relations. Social consciousness develops with the understanding that the social system has a history and it changes, leading to a sense of situatedness in a social world and a sense of civic responsibility to the common good.

A variety of researchers have conceived education as the most important site for the development of consciousness. Paulo Freire (2000) discusses the difference between a person's consciousness of themselves as the subject rather than the object of their situation. Education, for Freire, meant that a person can develop a "critical consciousness" and provide the person with a sense of their potential for agency. A similar concern for agency is put forth in research focusing on "civic consciousness" (Flanagan, 2001; Ladson-Billings, 1994; Lee, 2003) defined as "a critical consciousness about how to work for power within our democracy" (Lee, p. 45, 2003). Owens $\&$ Nowell (2001) define social consciousness as a thoughtful awareness of the social world. Within the Marxian tradition, the individual is usually considered an active participant in the social world, and consciousness is directly related to that activity (Leontiev, 1978). Marx conceptualizes social consciousness in dialectical relationship with material conditions, where consciousness is rooted in social being, i.e., social and economic relationships, that in turn can guide actions to change those conditions. Conscious life activity, according to Marx (1977), distinguishes humans from animals. I see these definitions as mutually informing and incorporate these insights into my initial concept of social consciousness. I define the concept as an interconnected three fold process including: an increasing awareness and critical understanding of the sociohistorical context; a sense of self as an agentive being situated and constituted in this context; and a sense of social/civic responsibility.

\section{Social consciousness and concept development}

Vygotsky (1987) discusses at length the dialectical relationship between everyday, spontaneous concepts and scientific concepts typically learned in the school context. The assent from the immediate spontaneous concept to mediated scientific concept through a series of abstractions and increasing determination is visible in activities requiring the child to consciously regard and manipulate the object 
of instruction with the assistance of a teacher. The goal of education, for Vygotsky, is making children's thinking more scientific. Science, in this way, involves inquiry, problem solving and the study of the process of things and their underlying systematic connections. When the content of study is the child's social world, it is important that curricula is relevant to their life, providing the opportunity to connect their personal experience to the greater historical context, enabling them to see the interconnections and the systematic nature of the world.

I am interested in the ways that the children as participants in this curriculum developed their social consciousness through teacher instruction, peer collaboration, and engagement with their lived environment, all mediated by photography, poetry and narrative. As Wendy Ewald (2001) emphasizes, photography enables youth to bring their home lives into school, helping teachers understand their lives, while encouraging youth to become more conscious of their surroundings and what may be everyday in their life.

\section{Art-based pedagogy as a vehicle of social consciousness}

"Art," writes Vygotsky, "is the social technique of emotion, a tool of society which brings the most intimate and personal aspects of our being into the circle of social life" (1971, p.249). Vygotsky's comment dramatically inverts the dominant romantic view of art as "self-expression" and instead insists on the social nature of artistic activity and its products. Although, not incompatible with a view of art as "self-expression" the recognition of art's social nature re-situates artistic endeavor in a social context and connects the individual and the social. Research illustrates the ways in which education improves expression, cognition and motivation as well as attitudes towards self, citizenship, and community (Ball \& Heath, 1993; Greene 1995; Sedgwick, 2000).
Art-based pedagogy, then, is a unique site allowing students to bring their out of school experience into the classroom.

Vygotsky's (1994) research into psychological abnormalities provided him with insight into the role played by imagination and fantasy in free conscious activity. He argues that without imagination and fantasy the subject is trapped within the immediate influences of external and internal stimuli:

We have seen that at this zero point of imagination, this absolute absence of fantasy can be observed because the person is unable to divert his attention from the concrete situation, to transform it creatively, to re-group the attributes and free him from the influence of the actual situation. (Vygotsky, 1994, p. 269)

It is through imagination that the subject can step outside of the immediacy, define alternative possibilities and anticipate the future. Maxine Greene (1995) discusses the unique ability of the arts, in particular poetry, to build the bridge between the real and the imaginary, allowing youth to explore "what is" as they develop problem solving and perspective-taking skills, explore social and cultural roles and conflict, and dream of what is possible ("what if").

Projects based in real life experience ground problem-solving and perspective-taking skills in relevant and meaningful ways. The importance of dreaming and imagining is especially significant and takes on a new role in the context of struggle against oppression. The ability to imagine a better world is the first step to actively creating it. In this way, imagination acts as a mediator of the "everyday"; it is an abstract place to grapple with material conditions and to develop possible solutions to social problems. 


\section{Metaphor and social consciousness}

Metaphor is an example of an art-based literary device that involves higher order thinking skills. The role of metaphor as a cognitive tool has been documented by researchers and philosophers for centuries. Metaphor, according to Aristotle, allows us to express new insights through utilizing the element of surprise. Metaphor is not merely a comparison of two objects, but allows communication of things that cannot be literally expressed (Winner,1982), for example, metaphor can be used to convey the vividness of phenomenon in a way that other linguistic devices cannot (Fainsilber \& Ortony, 1987). Metaphor, for cognitive linguists, serves as a bridge between already acquired knowledge and new knowledge. Lakoff and Johnson (1980) define the "conceptual metaphor" as a form of abstract reasoning mediating the "source domain," what is already known, and the "conceptual domain," the acquisition of new knowledge. Metaphor therefore plays an active role in the construction of new knowledge and the movement from the concrete to the abstract knowledge. In his critique of Lakoff and Johnson, Peter Jones (2001) puts forth a more social analysis of metaphor, as a tool to explore underlying social relationships.

As Carol Lee (1993) illustrates signification, an African - American oral discourse, involves the use of metaphor and irony in the out of school context. Lee focuses specifically on irony and the ways in which teachers can bring African-American children's out of school discourse into the classroom to develop their skills of literary analysis. The students involved in the study discussed in this paper are principally African-American. I am interested in their use of metaphor as a culturally relevant cognitive tool as they develop their social consciousness (defined as an interconnected three fold process including: an increasing awareness and critical understanding of the socio-historical context; a sense of self as an agentive being situated and constituted in this context; and a sense of social/civic responsibility).

\section{The "Where I Live" curriculum}

The project at the center of this study took place in a six-grade classroom in a poor and working-class African-American neighborhood in Newark, New Jersey. All sixth graders (approximately forty in all) participated in the project as part of the writing component of their language arts curriculum. The school divides students into four sections of about 15 students each.

The data presented in this paper is part of a larger research project that also examined the socio-historical context within which the project takes place. Multiple data sources included: an interview with the teacher, classroom observations, review of curriculum materials and discourse analysis of student work (the photography, poetry and narratives connected to the project).

Consent forms were received for 23 (22 African-American, 1 white) students across four classrooms of the same writing teacher. The students' final photograph is accompanied by a narrative on the topic "Where I Live" and a poem. Discourse analysis was conducted on 20 poems, 23 narrative essays, and 18 photographs that were the final product of the "Where I Live" curriculum.

All of the essays and poems were coded using Atlas ti software. Some sample codes include:

- Place - "Newark" - this code's purpose was to get a sense of the frequency of the use of the word "Newark" and to gain insight into the way children are connecting their everyday experience to the more abstract concept of the city in which they live. 
- Time - This code analyzed the ways in which the students discussed time- the past and the future- in relation to individual people and also to Newark as a city. A sub-code analyzed the discussion of "change" in the children's writing- in particular within the individual (ex. In the future I will...) and on the city level (ex. Newark used to be ...) and the interaction between the individual and social context. This code is important in gaining a sense of the students' connection between their immediate experience to the historical context and to the future.

- Metaphor - The metaphor code analyzes the student's use of metaphor in their writings, specifically, what purpose is metaphor serving, for example: for comparison or to develop concepts (conceptual metaphor); what themes are addressed by metaphor; as well as how metaphor interconnects with other codes such as time and place (facilitating the development of knowledge from the concrete/ immediate to the abstract/conceptual).

The curriculum began by historicizing the struggle for democracy as depicted and expressed through the arts. The teacher and the students studied poetry and documentary photography from social justice movements, like the Civil Rights Movement in the United States and related international movements. The youth were then given cameras of their own, and learned techniques of documentary photography, including the developing of the film.

Art history, in this conception, was not reduced to a history of artists in eternal dialogue with other artists, but instead presents artists interacting with their own historical context in addition to other artistic trends. Art history is then history mediated by the arts. In this project students were introduced to the vast artistic production coinciding with U.S. based and international social movements, including the Civil Rights Movement and anti-colonial movements. In addition, these movements were placed in a historical context mediated by the arts and this historicization helped situate students, and their artistic production in the present social context. In an interview with the teacher, she elaborated on the children's need for a more coherent understanding of African American history, which she teaches through the arts:

They don't understand, for example, that the Civil Rights Movement was different from the abolitionist movement... One thing we study in particular is this book, Freedom, that's an anthology of all documents of everything from slavery and pictures of slaves who wrote slave narratives or contributed to slave narratives to Klan activity to the Barakas and the 60 s. So that gives them kind of a timeline.

The students learned about the artist not only as documenter, but also an active participant in society. For example as the teacher explained the exhibit they visited on the work of photographer Bruce Davidson:

The stuff that Bruce Davidson did was really excellent when we went to study at the ICP, because what the curator had brought up was that the people documenting the Civil Rights Movement, the photographers weren't just documenting, but they were protecting the activists. They were protecting them, because there was always white lynch mobs following everywhere, but if you had a camera to record it, then they were less apt to attack you in a violent way.

The teacher used narrative, poetry and photography as tools with which the students could bring their personal everyday experience into the classroom for discussion and study. As part of the literacy curriculum, students discoursed on aesthetics and discussed possible criteria for making aesthetic judgments. A-historic ideals of "eternal beauty" and "objectively" good art were interrogated and challenged while alternative criteria for judging artistic endeavors, such as social relevancy, social commentary, social critique, and social impli- 
cations of artistic products emerged from student discussion or were offered as possibilities by the teacher. These discussions were brought to bear on poems by such artists as Roque Dalton, Langston Hughes, and Pablo Neruda. Students analyzed the poems for meaning, their technical and formal qualities and then wrote and shared their own poetry.

The students, as part of the literacy curriculum, wrote throughout the project. Students learned techniques for the creation of poetry. They studied poetic devices like alliteration, simile, metaphor and rhyme. They learned and practiced the process of planning, organizing, and editing essays. Writing assignments included answering such questions as "What is wrong with this picture?" or "How to make a Photogram" requiring them to critically think and apply their knowledge about the content and technical aspects of photography. For example in the following essay the student describes how to make a photogram:

\begin{abstract}
A photogram is something that records an image in black and white. Making a photogram takes hard work. You will need the following items: an enlarger, the developer, the fix and stop bath and photo paper with water too if you want your picture perfect. An enlarger is a machine that uses light to expose an image on photo paper.
\end{abstract}

She continues to explain the step-by-step process of creating a photogram that the students undertook as they learned how to use the equipment in the darkroom. She ends with an analysis of her photogram and she connects it to the art from the museum:

My picture has a lot of school supplies in it, erasers, sharpeners and my bracelet that has my name on it. The e's on my bracelet don't show up too well but, without e's it still spells my nickname. I think my picture is great. It reminds me of the zany picture I saw at the museum all the stuff were laid out as if they didn't care and that is where I got my idea. That picture was a role model for me.

As part of the project, the teacher took the students to a photography exhibit at the Newark Museum as well as to the International Center for Photography in New York City. The teacher also brought a number of documentary photography books into the classroom for the students to critique. They engaged in analytic discussions critiquing professional documentary photographers (such as Dorothea Lange), each other's, and their own work.

The students were given cameras of their own, and like the photographers they studied, their work was purposeful - they were recorders of the injustice in their own social- historical context. They were "standing on the shoulders of giants".

Before the students took the cameras home, they went out as a class to photograph their neighborhood, and to develop their photographic "eye". This activity of going out of the classroom and into the neighborhood illustrates the ability for photography to bridge the gap between home and school. Luis Moll (1990) comments cogently: "Meaning is found in the everyday- to make schooling significant one must go beyond the classroom walls" (p. 10).

\section{Social consciousness: Developing a more conscious awareness of "Newark"}

In the "Where I Live" curriculum students engaged in the social process of constructing new more determined concept of "Newark" as they connected their personal experience to knowledge learned in the class. Through the photography, writings and discussions, the children in this project develop their social consciousness (i.e., a more conscious awareness of the context, an understanding of themselves situated in the context and a sense of social responsibility) diachronically connecting their experience to the historical timeline, and synchronically addressing and connecting 
increasingly wider sets of social relations--immediate family and immediate neighborhood block linked to the more abstract city and civic level of understanding

The students took pictures of their everyday experience-wild dogs, graffiti that commemorates young people who have been killed, abandoned houses, vacant lots, litter. These photos then served as the base for meaningful discussions and critical essays about their community. Even seemingly innocuous objects like payphones and postboxes expressed deeper meaning for the students as they were brought in the classroom for study and discussion as shown in the examples of student photos and writings below:

Many people spend lots of money every day on payphones, or meters when it's not even worth it. Some things cost about 50 cents, some are more. If you do spend 50 cents or more to talk on a payphone or run a parking meter that is dirty or probably out order than you are wasting your money. However where I live machines that cost money are rarely taken care of.

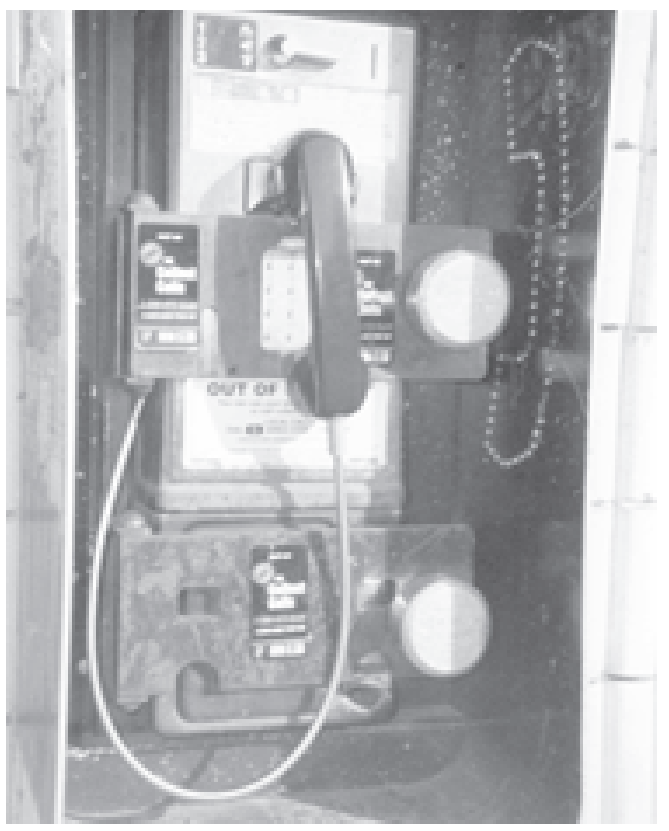

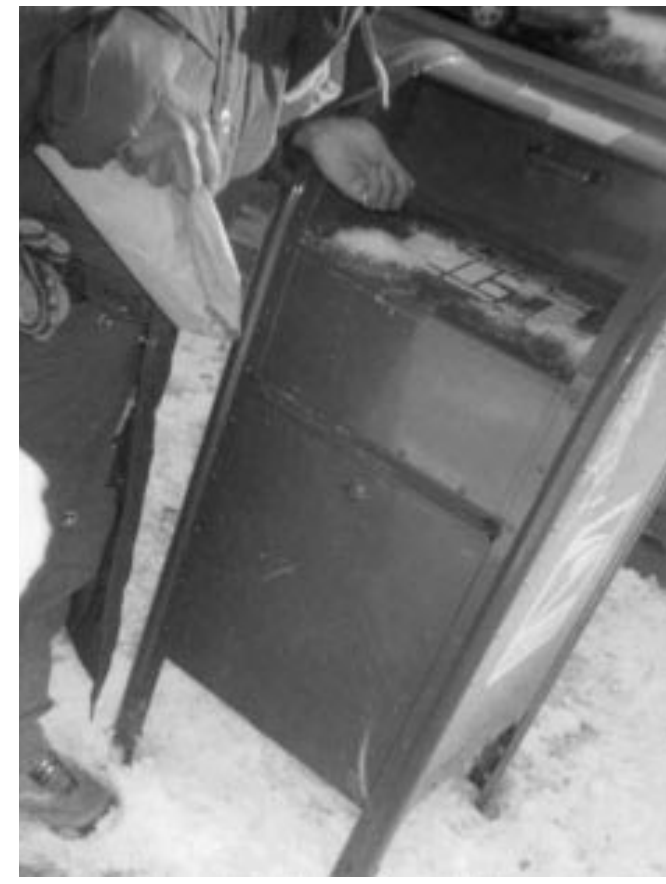

If you live where I live you could get killed when you walk out the door. You could get killed if you're going to the mailbox or going to the store for somebody that is older than you.

In their writings, students discussed the negative aspects of their community (gangs and drugs, abandoned houses, wild dogs) as well as their deep pride and love of their city. These experiences were sometimes conveyed through metaphor, for example, as one child wrote, "Cars are very dangerous nowadays. They are like Jason Voorhees from Friday the 13th movies, used as killing machines". Metaphor was used by two or three children to express the intensity of the love and friendship the children feel for the people in their community. For example, students wrote as "Where I live, friendship is like grass and water" and "my family is my heart".

Colette Daiute (2000) discusses how children from oppressed conditions develop a consciousness of their surroundings in a dynamic process, with tension arising from the students 
addressing social issues "head-on" and trying to make sense of an often contradictory world. Most of the essays were a working effort to negotiate these contradictions for themselves and the reader. Students often used metaphor as a way to express the fact that things can be two things at the same time, in particular, that the community they love is also very scary and dangerous:

Where I live

Is a two faced city

Where one half of the mask is terrific

And the other half is shameful and pitiful

While negotiating the duality of Newark for themselves, the students were also very conscious of the audience. The audience is conceived as a likely participant in the standard negative discourse about Newark as a dangerous place to live. Newark is dangerous, as the students insist, but they also raise the positive aspects elided in the standard discourse to defend their city.

There is not only horrible things that happen in Newark there is a delightful side too. It's just like Ying and Yang you have to have both so it can be balanced. Newark is a really balanced city It's also similar to Star Wars; there is the dark side and the light side. Even though the pandemonium that happens it is a great place to live. Take it from me, in Newark you can find really good friends.

In trying to make sense of the simultaneous negative and positive aspects of Newark, some of the children came to the conclusion that all places are good and bad, and Newark is not different. In the following example, the child draws an analogy between graffiti and Newark. Graffiti like Newark has a dual nature that it is not all bad:

Do you want to know how graffiti reflects on Newark, New Jersey? Newark to me is like a symbol of art, which is exactly what graffiti is ....Graf-

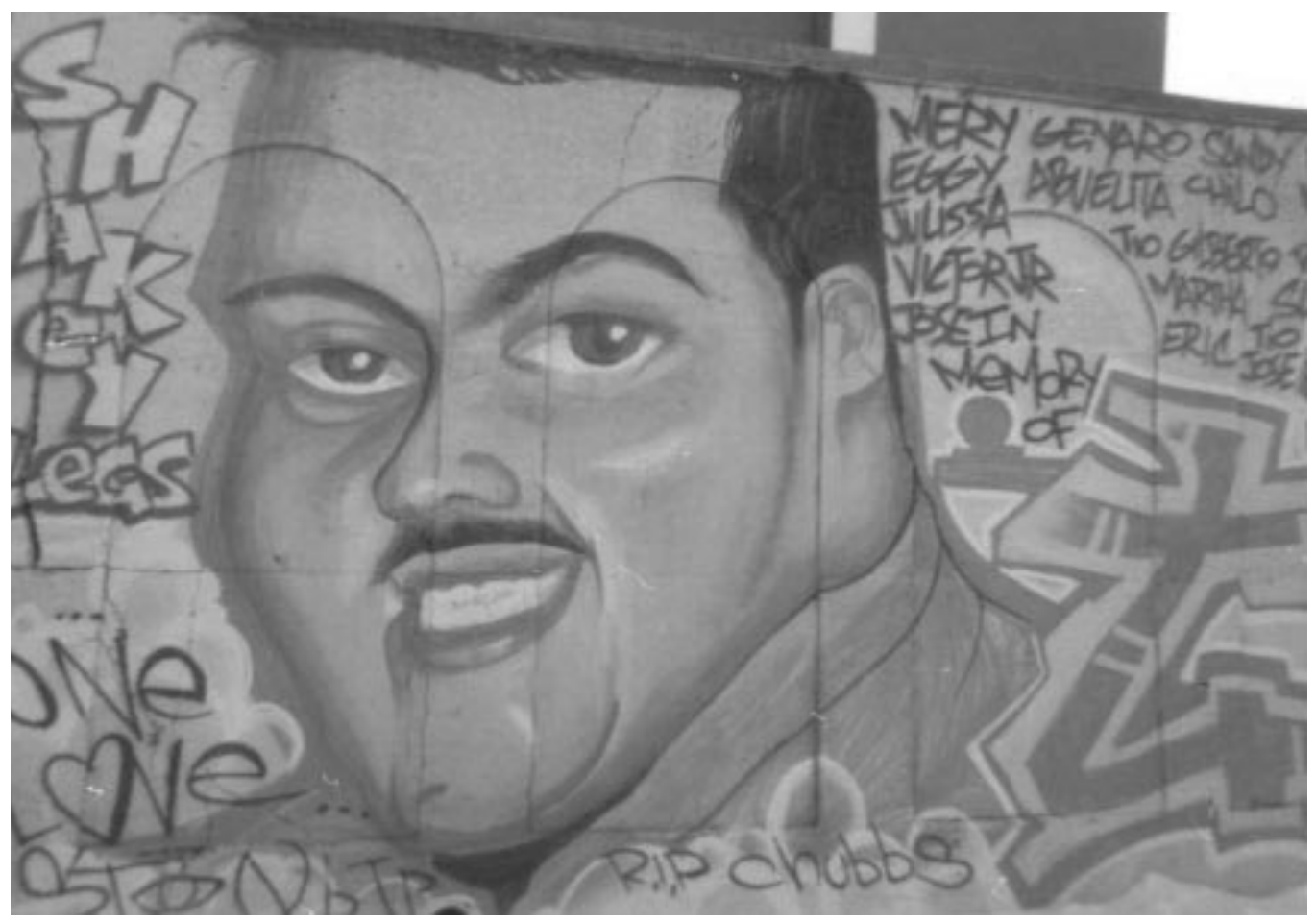


fiti has many different types of expression such as enchantment, dissatisfaction, and misery. That's exactly why graffiti reflects on Newark, New Jersey because these terminologies are just what Newark is full of. Newark is full of positives and negatives. ....But that's what makes where I live wonderful because nothing is perfect or $100 \%$ right Everything in this world is $50 \%$ wrong and $50 \%$ right. These are the reasons that graffiti reflects on the community I live in. Graffiti is also comparable to my place of birth because of the creativity.

In addition to emphasizing the duality of Newark and offering a counter to the standard negative discourse the student also offers an alternative conception of graffiti insisting on its categorization as "art." The student uses some of the tools learned in discussions of aesthetic criteria to defend a popular art form in the city and the city itself.

Students developed their concept of Newark as a contradiction between the positive and negative and as their understanding deepened and as their concept of Newark became increasingly determinate metaphor was used as a tool to investigate the difference between surface appearance and deeper knowledge. One student, for example, laments the hard learned fact that when walking down the street in Newark you have to be careful because people aren't always what they seem- finding people you can trust is "like finding a diamond in the rough." This example, however, was an exception. Most students made the opposite point: Newark may look "bad" but, beneath the surface it is good:

Newark is like a work of art with plenty of artists overflowing in it. If you were to look past the abandoned buildings, you see a work of fine art that someone put masses of time into. You wouldn't really see the boarded windows. Around where I live I see a lot of talent not being used to its full potential.

Students developing awareness of the city and their conceptualization are manifested in their use of the word "Newark." The word "New- ark" is repeated hundreds of times across their writings, as many as 25 times in one essay, this naming process reveals the formation and development of their concept and its increasing determination.

Their concept of Newark came to include areas of the city outside of their immediate experience as they name them and as they address the local, regional and national discourse about Newark, as seen in the following example:

All of Newark is not hostile. It's only certain parts like West Ward and Central Ward.

Sometimes it shames me to say where I was raised: The Capital of drugs and gang violence, Newark, New Jersey. One day at Central High School a boy was so brutally beaten that he was rushed away by an ambulance.

By naming places and people at the more abstract city level (i.e. "Newark", "Central and West Ward") they are able to make this level of experience more concrete. In another study focusing on politically active youth, I found when describing the problems facing their city, engaged youth named the forces working at the city level (the mayor, the city's name, etc.) while non-politically active youth did not (Ammentorp, 2001). The act of "naming," therefore, can be viewed as a tool for concretizing concepts and developing social consciousness.

\section{Social Consciousness:}

Understanding the "self" as situated in the socio-historical context and the development of social responsibility

All of the children involved in this project expressed a deep connection to the city in which they lived. The city was at once a source of joy and pride, but also of pain and despair. As one student eloquently expressed: "Sometimes the city has a big bomb on it, and it feels like it 
is going to explode on me." The project gave the students the ability to voice themselves as active participants of the community, as they connected their personal experience to history and expressed concern about the future. Significantly, students used metaphor to link their individual experience over time with changes in the larger context of Newark. One student, for example, photographed and wrote an essay based on the metaphor of a mirror as a window into the past and future of Newark which is inseparable from his own:

The history of Newark that I know about is when I lived on $23^{\text {rd }}$ Street. We had places we could go when we needed help for free. Now everywhere we go you either have to pay in advance or pay on a monthly basis. I know enough things to figure out that Newark is not a dreadful place to live in but it is an unsafe place for kids like me and younger than me. I' $\mathrm{m}$ still here? Yes, because I have no fear of being raised in Newark...... Do you think Newark will have a better reflection in the future? Yes, drugs will be off the streets of Newark, Yes, I will find my wife; I will teach and raise my child in Newark, and I will be a famous dancer.

In addition to connecting his future to the future of Newark, this example vividly expresses the students' conscious awareness of social injustice as well as his personal commitment to the city of Newark.

Weather and nature related metaphors were particularly powerful in connecting individual experience with changes in the larger sociohistorical context:

I live in Newark, New Jersey but I wasn't born here. I was born in Maryland where my grandpa,

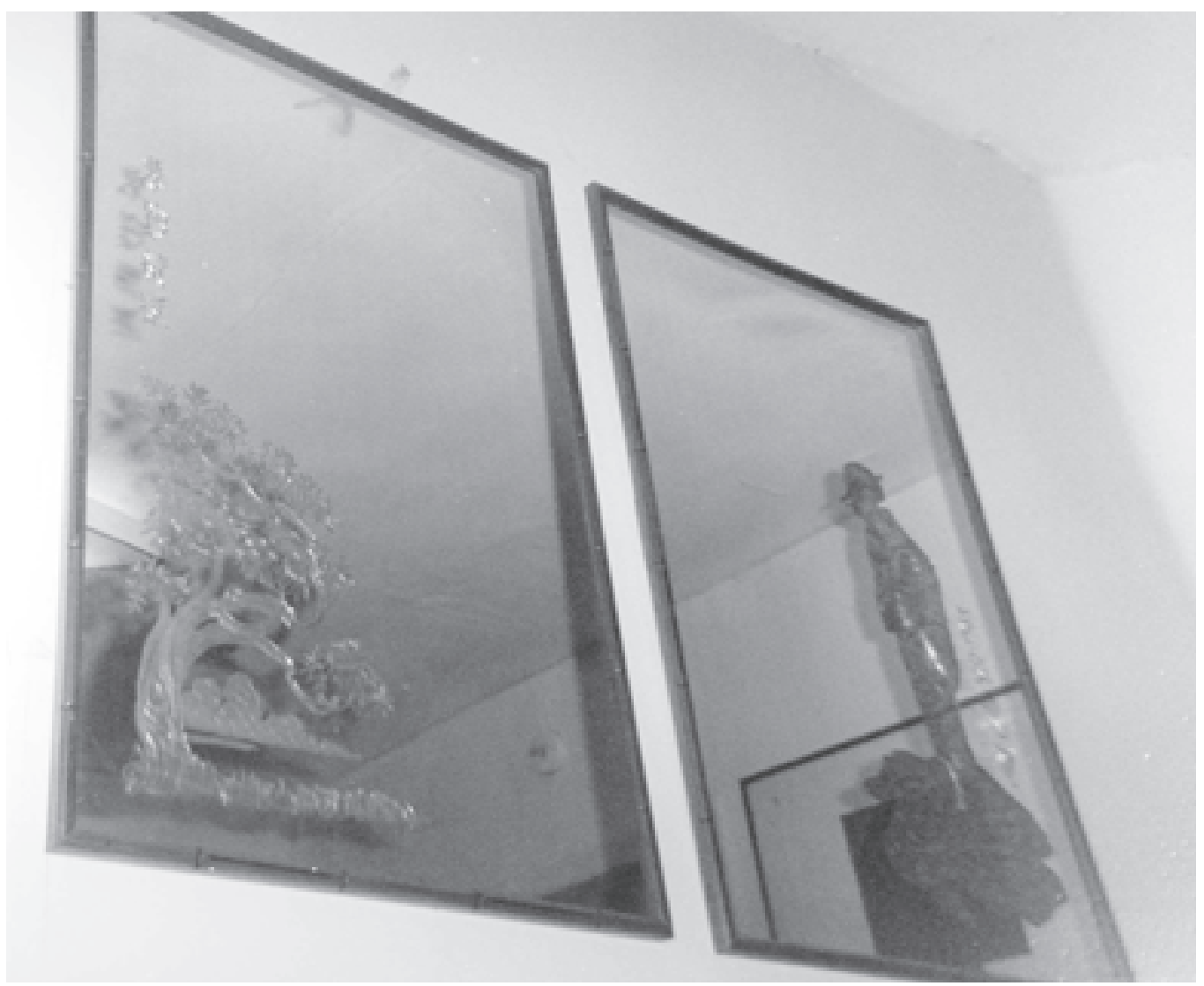


aunts and uncles, and nephews on my mother's side live. When I turned 3 years old, I moved to New Jersey. When living there, I saw beautiful cars and birds. There the sun would shine among the pretty clouds and you would hear the ice cream truck passing out ice cream and people walking past with their dogs and wow, the wonderful world it is!

...As years passed, the clouds darkened into gray and the world looked scary after September 11, 2001. Where the Twin Towers stood in New York there was a lot of killing. Afghanistan did an attack on the united states and now the united states is trying to get back at Afghanistan it all started at when each father of George Bush and the father of Saddam Hussein were presidents they had battle but they didn't finish so now the sons are battling after the fathers business.

The metaphor vividly expresses the narrative this student constructed of her life. She positions Maryland the place of her birth with beauty, peace, and the shining sun, and as she grows older and moves to Newark the clouds darken-- the world gets more complex as reflected in the bombing of the World Trade Center.

The use of metaphor to conceptualize individual and social change as a complex process came up frequently across the students' work. In the example below the student took a picture of an icicle on a pipe of a house, which served as a metaphor for the process of personal and social transformation:

Like a frozen icicle, all my problems freeze up, meaning that my problems are here and are not leaving. But sometimes my issues go away. Then the water freezes and it repeats the process again. It's like an icy waterfall. Solid ice that is unbreakable. In the spring and summer, ice melts and it's splendid. In the winter the water freezes up and it's not incredible. It grows into a sub-zero water ball with all the enjoyable things inside. Then summer comes back, and all those conflicts go away and

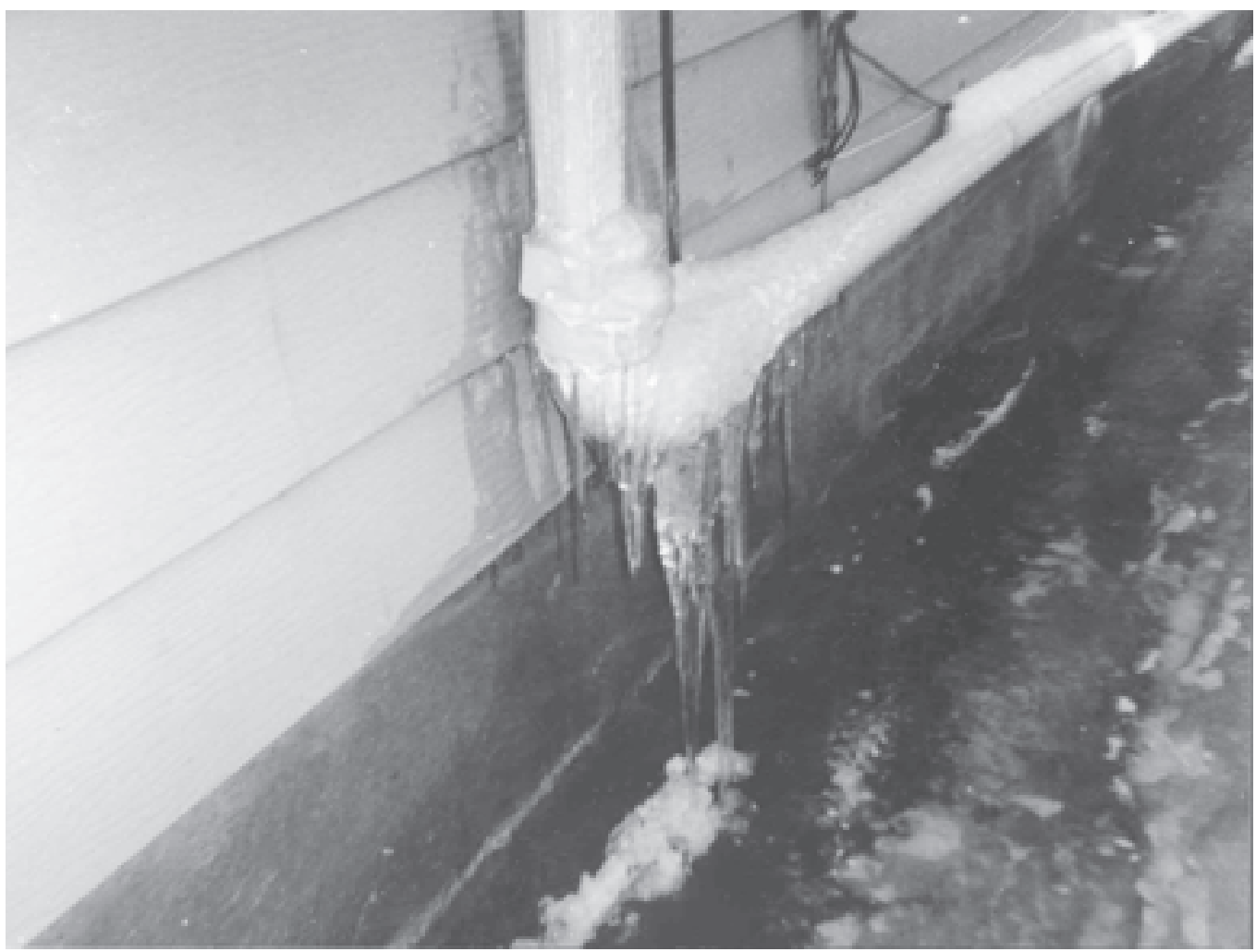


compassion and enthusiasm bursts out of that ball.

That is how the course of our struggles works.

There is a real sense of the complexity of the process and longterm aspect of the struggle for social change. Another student also used the image of ice melting as a metaphor for individual and social transformation:

We should melt our icy hearts.

We should crack our stony hearts.

We should destroy our black holes.

And bring new hearts

As I analyzed student work it became increasingly clear that it was the personal connection, the conscious situating of themselves in the social context that generated students' feelings of social responsibility. By directly confronting some of the most difficult issues facing the city and themselves in the classroom setting students began to imagine themselves as agents for change. Although the photographs were of their everyday experience, the children saw within it the kernel of what could be, the potential of their community and themselves.
The child who took the picture of the abandoned building below, for example, did not just describe the abandoned houses on his block, but metaphorically conveyed future possibilities: "Before the abandoned houses looked liked dead flowers but with the new houses, Newark would look like a bundle of roses".

The children studied the problems facing their community and included themselves in the solutions, as can be seen in the use of the word "we":

...The abandoned houses should also be replaced with cafés. There would be poetry reading from adults and children. On the walls there would be artwork, autographed instruments, and jazz musician posters. Cafés would serve coffee, cappuccino, donuts, cookies, and different type of snacks. The number one item served to the children in the cafés would be smoothies so everyone including the children and the adults would be satisfied. There's no limit to what we can do with these abandoned houses in Newark. We can create parks, arcades, pools, and more... Another alternative for abandoned houses are recreation centers. Recreation centers will provide a place for kids to be after

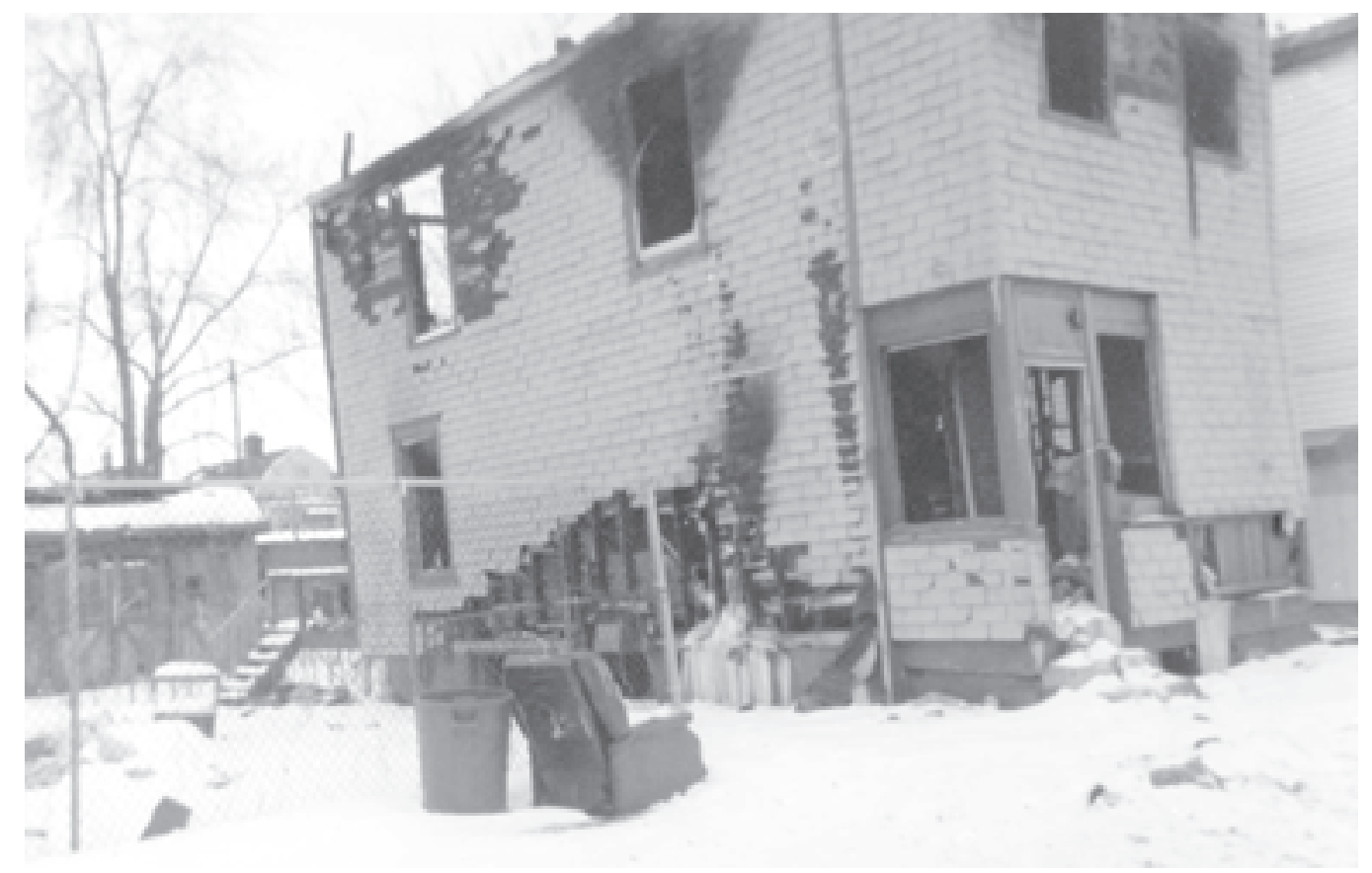


school and on the weekend. It would keep kids off of the street and become a home away from home for kids, teenagers, and adults. It would keep them busy and energized. It would provide jobs for teens and adults also.

The awareness of self as part of the community and thus responsible is captured in the title of one student's essay: "How I see Newark and myself". She concludes her essay with the statement: "Once you look carefully at Newark you ought to observe yourself within it. Wherever you live reflects you". In this way, developing a concept of Newark is a dynamic process that involves a thoughtful reflection on Newark as self, community, and home, which simultaneously encompasses feelings of joy and comfort as well as fear and pain, as illustrated in the following poem:

Newark

Where I come from so often,

People you grew up with,

are lying in a coffin.

My life is all I have,

My pencil, my poem, my notebook pad.

I've made it through the struggle,

All I need is someone to cuddle.

Abandoned houses on every block,

Newark is my home this is all I got.

If Martin Luther King Jr. were alive,

I think he'd want to cry.

To see all these horrible things,

When a person gets a hold of drugs they cling.

If Newark were alive and seen herself,

She'd be around screaming for help.

So if this is how they want to keep Newark for the rest of their lives,

I wrote this to make sure my dream for Newark never dies.

\section{Conclusion}

The children's work often startles the reader into recognition of the importance of meaning and relevance for an effective pedagogy. The issues emerging out of the students narratives are literally matters of life and death, and obviously create challenges for teaching since they are large scale social problems beyond easy solutions. However if these issues are not brought into the classroom then in-school activities become just a distraction from the more pressing concerns of students, like simply getting to a store and home again safely. And here an art-based pedagogy is especially effective, the teacher is not required to solve the problem for students, the problems are social and beyond the capacity of the teacher as an individual, but instead the teacher can offer the students artistic and intellectual tools and practical techniques for thinking through these issues, and together they can imagine possibilities for social change.

Surprisingly, although in conformity with expectations derived from previous research detailing metaphors relationship to cognition, students used metaphor far more often in their narratives then in their poetry. Social consciousness, I found, develops through metaphor making sense of complicated concepts and negotiating contradictions. Metaphor acted as a conceptual tool for increasing awareness of social context and mediates an increasing awareness that things aren't always as they appear on the surface and things can be two things at the same time. In connecting themselves to the greater social-historical context, metaphor assists the conceptualization of complex process of individual and social change.

Through the systematic study, mediated by the arts, of their city, Newark, and its underlying social relations students deepened their social consciousness, increasing their ability to discover and articulate causes of social problems and their possible solution. Within the context of an art-based pedagogy, students also developed their academic skills, in this case reading and writing, by engaging in meaningful work that required those skills.

The African-American students involved in 
this study live in some of the most challenging conditions in faced by children in the United States. Poverty, crime, drugs, marginalization, and despair are not exceptional but routine experiences. The "Where I Live Curriculum" assisted children as they struggle with this difficult issues, and aided their intellectual development. In my view, although these children have many unique qualities arising from their particular experiences, the success of this curriculum is not limited to children facing especially difficult circumstances. Although further research is clearly required this kind of curriculum which incorporates art-based activity with real issues facing children of any racial- socio-economic background has the potential to move school systems out of stifling rote-based irrelevant pedagogies.

In order for research and theory to inform public policy the goals of those policies must be clearly defined. If the goals of education are the development of the whole child: cognitively, emotionally, socially, and physically, and to develop skills and dispositions to be productive engaged citizens then greater effort is needed to develop art-based curriculums. What is the goal of educational policy based in the "standards" discourse? In a word it is testing. But testing students is clearly not teaching. Legislation like "No Child Left Behind" in the US is either poorly conceived and poorly thought out at best, or, at worst, designed to contribute to the de-skilling of a large segment of the future labor force and current and future teachers, creating an apartheid like system with a privileged few at the top while consigning large portions of the population to marginality and superfluity. What is needed, then, are alternative educational policies informed by research and theory.

\section{Acknowledgement}

This project would have been impossible without the enthusiasm and creativity of the school, the teacher and of course, the children. I would like to thank Keith Joseph for his valuable insight, support and continuous editorial assistance. I would also like to acknowledge the thoughtful suggestions by the reviewers of this article.

\section{References}

Ammentorp, L. (2001). Political activism and children's journalism: A case study of the Exit 9 'Zine. Unpublished Masters Thesis, The Graduate Center of the City University of New York.

Ball, A. \& Heath, S.B. (1993). Dances of identity: finding an ethnic self in the arts. In S.B. Heath \& M.W. McLaughlin (Eds.), Identity and inner-city youth: beyond ethnicity and gender (pp. 69-93). New York: Teachers College Press.

Center on Education Policy, From the Capital to the Classroom: Year 4 of the No Child Left Behind Act, Washington, D.C. March 2006.

Daiute, C. (2000). Narrative sites for youths' construction of social consciousness. Construction Sites. (pp. 211-234). New York: Teachers College, Columbia University.

Ewald, W. \& Lightfoot, A. (2001). I wanna take me a picture. Boston: Center for Documentary Studies in association with Beacon Press.

Fainsilber, L., \& Ortony, A. (1987). Metaphor production in the description of emotional states. Metaphor and Symbolic Activity, 2, 239-250.

Flanagan, C., \& Faison, N., (2001). Youth Civic Development: Implications of Research for Social Policy and Programs. Social Policy Report, 15.

Freire, P. (2000). Pedagogy of the oppressed. New York: Continuum.

Greene, M. (1995). Releasing the imagination: essays on education, arts and social change. San Francisco: Jossey-Bass Publishers.

Jones, P.E. (2001). Cognitive Linguistics and the Marxist approach to ideology. In R. Dirven, B. Hawkins \& E. Sandikcioglu (Eds.), Language and ideology. Volume 1: Theoretical cognitive 
approaches. (pp. 227-251). Philadelphia: John Benjamins Publishing Company.

Ladson-Billings, G. (1994). The dreamkeepers: Successful teachers of African American children. San Francisco: Jossey-Bass Publishers.

Lakoff, G. \& Johnson, M. (1980). Metaphors we live by. Chicago: University of Chicago Press.

Lee, C.D. (2003). Toward a framework for culturally responsive design in multimedia computer environments: Cultural modeling as a case. Mind, Culture and Activity: An International Journal, 10, 42-61.

Lee, C.D. (1993). Signifying as a scaffold for literacy interpretation: the pedagogical implications of an African American discourse genre. Urbana, IL: National Council of Teachers of English.

Leontiev, A.N. (1978). Activity, consciousness and personality. NJ: Prentice-Hall.

Marx, K. (1977) Capital: A critique of political economy. Volume 1. New York: Vintage Books.

Moll, L.C.(1990) Introduction. In L.C. Moll (Ed.), Vygotsky and Education Instructional Implications and Applications of Sociohistorical Psychology (pp. 1-27). Cambridge University Press.

Owens, W.T. \& Nowell, L.S. (2001). More than just pictures: Using picture story books to broaden young learners' social consciousness. Social Studies, 92, 33-41.

Sedgwick, F. (2000) Writing to learn: Poetry and literacy across the primary curriculum. New York: Routledge.

Vygotsky, L.S. (1971). The psychology of art. Cambridge, MA: MIT Press.

Vygotsky, L.S. (1987) The collected works of L.S. Vygotsky: Vol.1, Problems of general psychology. Including the volume Thinking and speech. New York: Plenum. (N. Minick, Trans.)

Vygotsky, L. S. (1994). Imagination and creativity of the adolescent. In Van Der Veer, R. \& Valsiner J., (Eds), The Vygotsky reader. Cambridge, MA: Blackwell Publishers

Winner, E. (1982). Invented worlds. Cambridge, MA: Harvard Press. 